\title{
No Early Effect of Storage Time of Transfused Red Blood Cells on Fatigue and Plasma Cytokines in Patients with Anaemia from Non-Acute Gastrointestinal Bleeding
}

\author{
Tommie Mynster $^{\mathrm{a}} \quad$ Morten Hanefeld Dziegiel $^{\mathrm{b}} \quad$ Kristian Kofoed $^{\mathrm{c}}$ \\ a Department of Surgery K, Bispebjerg Hospital H:S, University of Copenhagen, \\ ${ }^{b} \mathrm{H}: \mathrm{S}$ Blodbank, Rigshospitalet H:S, Copenhagen, \\ c Copenhagen University Hospitals, Hvidovre, Clinical Research Unit and Department of Infectious Diseases, Hvidovre, Denmark.
}

\section{Key Words}

Anaemia $\cdot$ IL-1 - Immunomodulation · Storage, TNF- $\alpha$.

Transfusion · Fatigue

\section{Summary}

Background: Fatigue in anaemia is empirically reduced by blood transfusion. Long storage time of red cells may be associated with immunomodulatory effects, and blood stored for a long time may cause tissue hypoxia upon transfusion. Patients and Methods: 22 patients admitted with haemoglobin $<6.0$ $\mathrm{mmol} / \mathrm{l}$, complaints of fatigue and no active bleeding were in cluded. Eleven patients received two red cells units (SAGM) stored less than 1 week (short storage time, S), and 11 patients received two units stored more than 3 weeks (long storage time, L). Fatigue was self-estimated on a visual analogue scale. Clinical observations and blood samples were obtained before transfusion was started, and were repeated 2-8 h after transfusion of the 2nd unit. Measured plasma parameters included IL$1 \beta$, IL-6, IL-8, IL-10, IL-12 and TNF- $\alpha$. Results: There were no significant differences between group $S$ and $L$ (nsSL) in demographic data, observational data and blood plasma values. Haemoglobin increased from mean ( \pm SD) $5.2 \pm 0.6$ to $6.4 \pm 0.7$ $\mathrm{mmol} / \mathrm{l}$ after transfusion (nsSL). Fatigue score significantly decreased from a pre-transfusion median 6.6 (range 0.1-9.9) to post-transfusion $4.7(0.6-10.0)(p=0.02)$ for all patients (nsSL). Beside increase in haemoglobin the only significant change in blood parameters after transfusion was a decrease in thrombocyte count (nsSL). No significant differences were seen in concentrations of cytokines before and after transfusion. Conclusion: Transfusion of two units of red cells relieved self-estimated fatigue, independent of blood storage time. Thrombocyte count decreased after transfusion, probably due to dilution by transfused blood. Aged red cells may not, or only sparsely, directly trigger the interleukin cascade.

\section{Schlüsselwörter}

Anämie · IL-1 - Immunmodulation · Lagerung · TNF- $\alpha$. Transfusion - Fatigue

\section{Zusammenfassung}

Hintergrund: Fatigue bei Anämie kann, wie empirisch belegt, durch eine Bluttransfusion reduziert werden. Eine lange Lagerungszeit der Erythrozyten ist möglicherweise mit immunmodulatorischen Effekten verbunden ebenso wie lang gelagertes Blut möglicherweise eine Hypoxie bei Transfusion verursacht. Patienten und Methoden: 22 Patienten, die in unsere Klinik mit einem Hämoglobinwert <6,0, Fatigue-Beschwerden, aber ohne aktive Blutung eingewiesen wurden, wurden in die Studie eingeschlossen. Elf Patienten erhielten je zwei Erythrozytenkonzentrate (SAGM), die weniger als 1 Woche (kurze Lagerungszeit; S) gelagert worden waren, die anderen 11 Patienten je zwei Erythrozytenkonzentrate, die mehr als 3 Wochen (lange Lagerungszeit; L) gelagert worden waren. Der Grad der Fatigue wurde mittels Selbsteinschätzung auf einer visuellen Analogskala bestimmt. Klinische Untersuchungen und Blutprobenentnahme wurden vor Beginn der Transfusion und 2-8 h nach der Transfusion des zweiten Erythrozytenkonzentrats durchgeführt. Folgende Plasmaparameter wurden bestimmt: IL-1 13 , IL-6, IL-8, IL-10, IL-12 und TNF- $\alpha$. Ergebnisse: In Bezug auf die demographischen Daten, die Untersuchungsergebnisse und die Blutwerte gab es keine signifikanten Unterschiede zwischen Gruppe $S$ und $L$ (nsSL). Der Hämoglobinwert stieg von 5,2 $\pm 0,6$ (Mittelwert \pm SD) vor auf $6.4 \pm 0.7 \mathrm{mmol} / \mathrm{l}$ nach der Transfusion (nsSL). Der Fatigue-Score reduzierte sich signifikant von einem prätransfusionellen Median von 6,6 (Bereich 0,1-9,9) auf 4,7 $(0,6-10,0)$ nach der Transfusion (nsSL). Der einzige Veränderung der Blutwerte neben dem Hämoglobinanstieg war die Abnahme der Thrombozytenzahl (nsSL). Die Konzentrationen der Zytokine waren durch die Transfusion nicht signifikant verändert. Schlussfolgerung: Die Transfusion von zwei Erythrozytenkonzentraten verbessert den durch Patienten selbst eingeschätzten Fatigue-Wert unabhängig von Lagerungsdauer des Bluts. Die Thrombozytenzahl nimmt nach der Transfusion ab - möglicherweise aufgrund der Verdünnung durch das transfundierte Blut. Ältere Erythrozyten scheinen die Interleukinkaskade gar nicht, oder nur sehr gering, zu triggern.

\begin{tabular}{|c|c|}
\hline KARGER & (c) 2007 S. Karger GmbH, Freiburg \\
\hline $\begin{array}{l}\text { Fax +497614520714 } \\
\text { E-mail Information@Karger.de } \\
\text { www.karger.com }\end{array}$ & $\begin{array}{l}\text { Accessible online at: } \\
\text { www.karger.com/tmh }\end{array}$ \\
\hline
\end{tabular}




\section{Introduction}

One of the indications for red cell transfusion in non-acute anaemia is to relieve symptoms such as fatigue, headache, dyspnoea and palpitations. It is known that increasing the haemoglobin concentration by erythropoietin in cancer patients decreases the level of fatigue [1]. In the clinical everyday practice, blood transfusion may relieve the symptoms, but not always so. Red blood cell transfusions may improve subjective well-being in only $50 \%$ of terminally ill cancer patients, and this is not clearly associated with relieve in fatigue [2].

Long storage of red cells may change the cells and hence generate immunomodulation in the recipient [3]. The studies of immune parameters after blood transfusion are however primarily based on in vitro and animal studies. Previous human in vivo studies have often been done in patients undergoing surgery. The patients studied have not been stratified to postoperative infectious complications and varying storage time of transfused blood $[4,5]$. The potential immunomodulatory effect of blood transfusion is probably only detectable after stimulation of the immune system by danger signals [3], i.e. surgery, infection, or trauma. Red cells units may, however, under certain other circumstances trigger the immune system as leucocytosis within a few hours after transfusion is more frequent in non-septic than in septic intensive care patients [6].

Immunological markers previously shown to be affected by blood transfusion are TNF- $\alpha$, IL-2 and IL-10 [3]. Several cytokines are indicated to be involved in fatigue associated with cancer [7]. We, therefore, performed this study of the impact of storage time of transfused blood on anaemia-associated fatigue and on immunological markers

\section{Patients and Methods}

The Scientific Ethical Committee of Copenhagen and Frederiksberg approved the study (KF 01-212/03), and patients were included on the basis of informed written consent.

26 patients admitted to our surgical gastroenterology department with haemoglobin $<6.0 \mathrm{mmol} / \mathrm{l}$, complaints of fatigue and no active bleeding ( $<300 \mathrm{ml} /$ day) or signs of blood pressure instability were consecutively included from April 2004 to February 2005. The following categories of patients were not included: patients with known immunological disorders or infections, patients not expected to understand the visual analogue scale (VAS), and patients who had undergone surgery or received blood transfusion within 2 months. Randomisation was done immediately after admission and inclusion. Each patient received two units of red cell suspension; 13 patients received two units stored less than 1 week (group S) and 13 patients received two units stored more than 3 weeks (group L).

A unit of blood is produced by drawing $450 \mathrm{ml}$ of whole donor blood into a blood bag with $63 \mathrm{ml}$ CPD solution (Baxter A/S, Alleroed, Denmark). The bag is subsequently subjected to centrifugation, plasma and buffy coat are removed, and red cells are transferred to a separate blood bag containing $100 \mathrm{ml}$ saline, adenine, glucose and mannitol (SAGM) solution. This results in a red cell suspension of approximately $275 \mathrm{ml}$ with a $65-75 \%$ leucocyte reduction and a haematocrit of $60 \%$.
Table 1. Demographic data and disease characteristics of the 22 patients receiving transfusion of blood of short or long storage time

\begin{tabular}{lll}
\hline & Group S & Group L \\
\hline Age, median (range), years & $73(31-89)$ & $68(54-88)$ \\
Female/male & $6 / 5$ & $6 / 5$ \\
ASA group & & \\
I & 2 & 1 \\
II & 6 & 7 \\
III & 3 & 3 \\
Bleeding source & & \\
Peptic & 2 & 6 \\
Colon/rectum & 6 & 4 \\
Unknown & 3 & 1 \\
Diagnoses (yes/no) & & \\
Cancer & $5 / 6$ & $3 / 8$ \\
CVD & $8 / 3$ & $8 / 3$ \\
CLD & $0 / 11$ & $3 / 8$
\end{tabular}

ASA = American Society of Anaesthesiologists; CVD = cardiovascular disease; CLD = chronic lung disease.

Fatigue was self-estimated on a VAS (no fatigue $=0$, maximal fatigue $=$ 10) before and $2-8 \mathrm{~h}$ after transfusion. VAS score of fatigue (lack of energy) is one of 10 items in the Edmonton Symptom Assessment Scale validated for graphic display of symptom intensity in patients e.g. cancer patients [8]. The patient and the interviewer were blinded of the unit storage time. Clinical observations and blood samples were obtained immediately before transfusion and 2-8 $\mathrm{h}$ after transfusion of the 2 nd unit, which was started within $3 \mathrm{~h}$ after the start of first transfusion.

Measured blood and plasma parameters included total leucocyte count and differential count, thrombocyte count, international normalized ratio (INR), activated partial thromboplastin time (APTT), antithrombin-3, D-dimer, fibrinogen and C-reactive protein measured using the Roche Tina-quant CRP Immunoturbidimetric assay (Roche Diagnostics $\mathrm{GmbH}$, Mannheim, Germany) on a Hitachi 917.

\section{Collection and Storage of Blood Samples}

Blood samples were collected by venipuncture into K2 EDTA-containing Vacutainer Tubes (BD Bioscience, San Jose, CA, USA). Blood was centrifuged at $3,000 \times g$ for $10 \mathrm{~min}$ at $4{ }^{\circ} \mathrm{C}$. Plasma was then separated and subsequently stored at $-80{ }^{\circ} \mathrm{C}$ in aliquots.

\section{Cytokine Assay}

Plasma concentrations of IL-1 $\beta$, IL-6, IL-8, IL-10, IL-12 (p70), and TNF- $\alpha$ were measured using the Beadlyte ${ }^{\mathrm{TM}}$ human multicytokine detection system 2 from Upstate Cell Signalling Solutions (Lake Placid, NY, USA). The assay was performed according to the manufacturer's instructions. Briefly, the lyophilized multicytokine standard was re-suspended in human Beadlyte serum standard diluents and then 1:3 serially diluted from 5,000 to $6.9 \mathrm{pg} / \mathrm{ml}$. To each designated pre-wetted well of a 96-well filter plate $50 \mu \mathrm{l}$ standard or 1:1 diluted sample (diluted in Beadlyte human serum diluents) and $25 \mu \mathrm{l}$ of the bead solution were added. After $2 \mathrm{~h}$ incubation at room temperature the reporter solution was added. The streptavidin-phycoerythrin solution diluted 1:25 in assay buffer was added after an additional incubation of $1.5 \mathrm{~h}$ at room temperature. After a final incubation at room temperature for $30 \mathrm{~min}$ and the addition of the stop solution, the plate was placed on the XY platform of the Luminex100 (Luminex Corp., Austin, TX, USA) and analysed using StarSation v.2 software from Applied Cytometry Systems (Sheffield, UK). From each well, a minimum of 100 analyte-specific beads was analysed for both bead designation and RPE fluorescence. 
Table 2. Physical, biochemical and haematological preand post-transfusion data from the 22 patients pre- and posttransfusion of blood of short or long storage time

\begin{tabular}{|c|c|c|c|c|}
\hline & \multicolumn{2}{|l|}{ Group S } & \multicolumn{2}{|l|}{ Group L } \\
\hline & pre-transfusion & post-transfusion & pre-transfusion & post-transfusion \\
\hline Systolic pressure, $\mathrm{mm} \mathrm{Hg}$ & $130 \pm 31$ & $148 \pm 23$ & $125 \pm 26$ & $131 \pm 26$ \\
\hline Diastolic pressure, $\mathrm{mm} \mathrm{Hg}$ & $64 \pm 11$ & $75 \pm 8^{*}$ & $66 \pm 12$ & $70 \pm 9^{*}$ \\
\hline Heart rate & $74 \pm 15$ & $72 \pm 11$ & $85 \pm 17$ & $87 \pm 15$ \\
\hline Temperature, ${ }^{\circ} \mathrm{C}$ & $36.7 \pm 0.5$ & $37.1 \pm 0.5$ & $37.1 \pm 0.9$ & $37.1 \pm 0.5$ \\
\hline Haemoglobin $\mathrm{mmol} / \mathrm{l}$ & $5.1 \pm 0.6$ & $6.3 \pm 0.7 *$ & $5.2 \pm 0.6$ & $6.6 \pm 0.7 *$ \\
\hline Leucocytes $\times 10^{9} / 1$ & $8.3 \pm 2.2$ & $8.3 \pm 2.7$ & $9.1 \pm 3.2$ & $8.9 \pm 3.4$ \\
\hline Neutrophils & $5.9 \pm 2.0$ & $5.7 \pm 2.2$ & $6.7 \pm 2.8$ & $6.5 \pm 3.4$ \\
\hline Eosinophils & $0.2 \pm 0.2$ & $0.3 \pm 0.2$ & $0.2 \pm 0.1$ & $0.3 \pm 0.3$ \\
\hline Basophils & $0.04 \pm 0.04$ & $0.05 \pm 0.05$ & $0.05 \pm 0.03$ & $0.03 \pm 0.03$ \\
\hline Lymphocytes & $1.6 \pm 0.5$ & $1.7 \pm 0.7$ & $1.7 \pm 0.9$ & $1.5 \pm 0.9$ \\
\hline Monocytes & $0.6 \pm 0.3$ & $0.7 \pm 0.2$ & $0.7 \pm 0.4$ & $0.8 \pm 0.4$ \\
\hline Thrombocytes $\times 10^{9} / 1$ & $312 \pm 132$ & $284 \pm 116^{*}$ & $345 \pm 126$ & $308 \pm 115^{*}$ \\
\hline C-reactive protein, $\mathrm{mg} / \mathrm{l}$ & $38 \pm 52$ & $38 \pm 52$ & $49 \pm 55$ & $56 \pm 68$ \\
\hline $\mathrm{TNF}-\alpha, \cdot \mathrm{pg} / \mathrm{ml}$ & $10 \pm 9$ & $9 \pm 10$ & $12 \pm 8$ & $11 \pm 6$ \\
\hline IL- $1 \beta, p g / m l$ & $15 \pm 11$ & $13 \pm 11$ & $17 \pm 10$ & $17 \pm 10$ \\
\hline IL-6, pg/ml & $14 \pm 13$ & $16 \pm 16$ & $31 \pm 26$ & $28 \pm 15$ \\
\hline IL-8, pg/ml & $28 \pm 38$ & $27 \pm 43$ & $18 \pm 26$ & $20 \pm 28$ \\
\hline $\mathrm{IL}-10, \mathrm{pg} / \mathrm{ml}$ & $5 \pm 4$ & $5 \pm 4$ & $7 \pm 3$ & $7 \pm 6$ \\
\hline $\mathrm{IL}-12, \mathrm{pg} / \mathrm{ml}$ & $32 \pm 23$ & $30 \pm 25$ & $36 \pm 27$ & $33 \pm 23$ \\
\hline
\end{tabular}

* = Significant difference $(\mathrm{p}<0.05)$ between pre- and post-transfusion within group S or group L.

\section{Statistical Analysis}

With an expected standard deviation of $20 \%$ and risk of type 2 error of $10 \%$, it was calculated that to detect a difference in VAS score of $30 \%$; 20 patients $(2 \times 10)$ had to be included. Differences between cytokine concentrations before and after transfusion were tested using paired samples t-tests. Independent samples t-tests were used to compare differences in cytokine concentrations in group S vs. group L. Normal distribution of plasma cytokine values was tested with one-sample KolmogorovSmirnov's test. Differences in VAS scores were analysed with non-parametric tests. The results are expressed as mean \pm SD when not otherwise indicated, and a $p$ value less than 0.05 was considered significant. All statistical analyses were performed with the SPSS 13.0 software program.

\section{Results}

Initially 26 patients were included. Four patients were subsequently excluded, two because of transfusion with blood of incorrect storage time, one had sudden active bleeding during transfusion, and one had X-ray-verified pneumonia. Excluded patients were equally belonging to group $\mathrm{S}$ and group L, resulting in a total of 22 patients with 11 in each group. In all, 8 patients suffered from cancer, 1 with breast cancer and 7 with colon cancer. There were no significant differences between groups $\mathrm{S}$ and $\mathrm{L}$ (nsSL) with regard to demographic data (table 1). Median storage time of blood transfused in group $\mathrm{S}$ was 4.5 days (range 1-7 days), and in group L median storage time of blood was 27 days (range 23-34 days). Each patient received two units of blood with less than 2 days difference in storage time.
Haemoglobin increased in all patients from mean $5.2 \pm 0.6$ to $6.4 \pm 0.7 \mathrm{mmol} / \mathrm{l}$ after transfusion (nsSL). The only other significant change in blood parameters after transfusion was a decrease $(\mathrm{p}<0.01)$ in thrombocyte count in all patients from $330 \pm 127$ to $296 \pm 113 \times 10^{9} / 1(\mathrm{nsSL})$. The only significant change in clinical observational data after blood transfusion was an increase $(\mathrm{p}<0.01)$ in diastolic pressure in all patients from $65 \pm 11$ to $73 \pm 9 \mathrm{~mm} \mathrm{Hg}$ (nsSL) (table 2).

Self-estimated fatigue score significantly decreased from median 6.6 (range $0.1-9.9)$ to 4.7 (range $0.6-10.0)(\mathrm{p}=0.02)$ for all patients. The fatigue score decreased in group $\mathrm{S}$ from 6.2 to 3.4 and in group L from 6.8 to 6.4 (nsSL). Although this difference may seem significant, it was not; due to variability and equally distribution of individuals reporting increase in fatigue (fig. 1).

Plasma cytokine levels showed some variation, but pre-transfusion levels were not significantly different from post-transfusion levels. Likewise, there were no significant differences within group S and group L (table 2). As an example of the variation in cytokine concentration the values of IL-1 $\beta$ are shown in figure 2.

There was a significantly higher plasma level of C-reactive protein in patients with cancer (table 3). Higher levels of IL$1 \beta$, TNF- $\alpha$, IL-6, IL- 8 and IL-12 also reflected inflammation, but significant differences were only seen with IL-1 $\beta$ and IL6 . There was no significant change in any inflammatory marker after transfusion, even after stratification for diagnosis (table 3). 
Table 3. Physical, biochemical and haematological preand post transfusion data on the 22 patients; 14 without cancer diagnosis and 8 with cancer diagnosis

\begin{tabular}{|c|c|c|c|c|}
\hline & \multicolumn{2}{|c|}{ Non-cancer patients } & \multicolumn{2}{|l|}{ Cancer patients } \\
\hline & pre-transfusion & post-transfusion & pre-transfusion & post-transfusion \\
\hline Systolic pressure, $\mathrm{mm} \mathrm{Hg}$ & $123 \pm 29$ & $134 \pm 29$ & $136 \pm 25$ & $148 \pm 15$ \\
\hline Diastolic pressure, $\mathrm{mm} \mathrm{Hg}$ & $63 \pm 10$ & $69 \pm 8$ & $70 \pm 13$ & $79 \pm 5^{\#}$ \\
\hline Heart rate & $75 \pm 17$ & $78 \pm 16$ & $86 \pm 16$ & $83 \pm 15$ \\
\hline Temperature, ${ }^{\circ} \mathrm{C}$ & $36.7 \pm 0.7$ & $37.0 \pm 0.6$ & $37.2 \pm 0.7$ & $37.4 \pm 0.3$ \\
\hline Haemoglobin, $\mathrm{mmol} / \mathrm{l}$ & $4.9 \pm 0.6$ & $6.2 \pm 0.6$ & $5.6 \pm 0.4^{\#}$ & $6.9 \pm 0.4^{\#}$ \\
\hline Leucocytes $\times 10^{9} / 1$ & $7.6 \pm 1.9$ & $8.3 \pm 2.7$ & $10.6 \pm 3.0^{\#}$ & $10.1 \pm 3.3$ \\
\hline Neutrophils & $5.4 \pm 2.0$ & $5.3 \pm 2.8$ & $7.7 \pm 2.3^{\#}$ & $7.3 \pm 2.6$ \\
\hline Eosinophils & $0.2 \pm 0.2$ & $0.3 \pm 0.3$ & $0.2 \pm 0.1$ & $0.2 \pm 0.1$ \\
\hline Basophils & $0.05 \pm 0.04$ & $0.05 \pm 0.05$ & $0.04 \pm 0.02$ & $0.03 \pm 0.01$ \\
\hline Lymphocytes & $1.5 \pm 0.7$ & $1.5 \pm 0.9$ & $1.9 \pm 0.7$ & $1.8 \pm 0.8$ \\
\hline Monocytes & $0.5 \pm 0.2$ & $0.6 \pm 0.2$ & $0.8 \pm 0.4$ & $0.8 \pm 0.4$ \\
\hline Thrombocytes $\times 10^{9} / 1$ & $263 \pm 87$ & $234 \pm 75$ & $439 \pm 106^{\#}$ & $398 \pm 90^{\#}$ \\
\hline C-reactive protein, $\mathrm{mg} / \mathrm{l}$ & $19 \pm 39$ & $24 \pm 56$ & $80 \pm 50^{\#}$ & $81 \pm 49^{\#}$ \\
\hline $\mathrm{TNF}-\alpha, \mathrm{pg} / \mathrm{ml}$ & $9 \pm 9$ & $7 \pm 8$ & $14 \pm 8$ & $14 \pm 7$ \\
\hline IL- $1 \beta, p g / m l$ & $13 \pm 10$ & $11 \pm 8$ & $21 \pm 9$ & $22 \pm 11^{\#}$ \\
\hline $\mathrm{IL}-6, \mathrm{pg} / \mathrm{ml}$ & $19 \pm 25$ & $14 \pm 12$ & $30 \pm 16$ & $35 \pm 14^{\#}$ \\
\hline IL-8, pg/ml & $13 \pm 21$ & $12 \pm 23$ & $40 \pm 42$ & $43 \pm 46$ \\
\hline $\mathrm{IL}-10, \mathrm{pg} / \mathrm{ml}$ & $5 \pm 4$ & $5 \pm 5$ & $8 \pm 5$ & $8 \pm 5$ \\
\hline $\mathrm{IL}-12, \mathrm{pg} / \mathrm{ml}$ & $28 \pm 21$ & $24 \pm 20$ & $44 \pm 28$ & $35 \pm 26$ \\
\hline
\end{tabular}

\#Significant difference $(\mathrm{p}<0.05)$ between cancer and non-cancer patients within 'pre-transfusion' and 'post-transfusion'.

\section{Discussion}

Blood units may accumulate bioactive substances during storage which, in theory, could modulate the recipient's immune system after transfusion [3]. Increasing concentrations of TNF- $\alpha$, IL-1 $\beta$, IL-6 and IL-10 in SAGM units after long storage have previously been reported, however, not exceeding in vivo plasma levels [3]. In contrast, IL-8 is reported to attain concentrations of $300 \mathrm{pg} / \mathrm{ml}$ [9], which is $5-10$ times higher than normal plasma levels.

In the present study no significant changes in immunological markers were observed after infusion of two units of erythrocyte suspension. This supports previous results indicating that SAGM blood during cold storage do not accumulate cytokines in amounts sufficient to increase post-transfusion plasma levels [3]. Obviously, additive amounts with transfusion of cytokines like IL- 8 may have been diluted and metabolised within a few hours. The only observed direct effect of blood transfusion was an increase in haemoglobin and a decrease in thrombocyte count. A decrease in thrombocyte count had to be expected when using buffy coat-depleted SAGM erythrocyte suspension, which practically is devoid of thrombocytes.

With infusion of antigens to humans, response time to peak levels of cytokines like TNF- $\alpha$, IL- 6 and IL- 8 are within a few hours [10-12]. Therefore, if the blood transfusions had exerted a direct antigenic effect we would have expected a significant cytokine response within the time frame of the study. Previous studies have shown that substances released from disintegrating granulocytes during storage of blood, e.g. myeloperoxidase from neutrophils and eosinophilic cationic protein from eosinophils, also have a potential of modulating cytokine profiles [3]. Similarly, although in vitro, it has been shown that stored red cells may cause immunomodulation and IL-8 release. This has been suggested to be due to stimulation by red cell membrane-derived lipids which are accumulated in the supernatant of blood units during storage [13]. These effects could not be demonstrated in our in vivo study by transfusion of two units of blood of approximately $550 \mathrm{ml}$ red cell suspension. It is possible that transfusion of a higher number of units could have induced a detectable secretion of cytokines. However, it has previously been shown in in vitro studies that only one erythrocyte unit could cause a reduction in stimulated TNF- $\alpha$ release with a concomitantly increased IL-10 secretion from whole blood-derived recipient cells [14]. The reason for not finding this effect in the present study may have been an insufficient stimulation of immune cells. There was no additional antigen stimulation simultaneously with the in vivo blood transfusion in the present study, but the transfused donor blood definitely served as an alloantigeneic stimulus. There was an increased C-reactive protein level (normal upper limit $<10 \mathrm{mg} / \mathrm{ml}$ ), probably due to disease and anaemia. It was possible to detect differences in inflammatory status between cancer and non-cancer patients. This indicates that it would have been possible to detect expectable effects on immune parameters within the study size, but it also indicates that in vitro study results may not be directly transferable to in vivo conditions. 


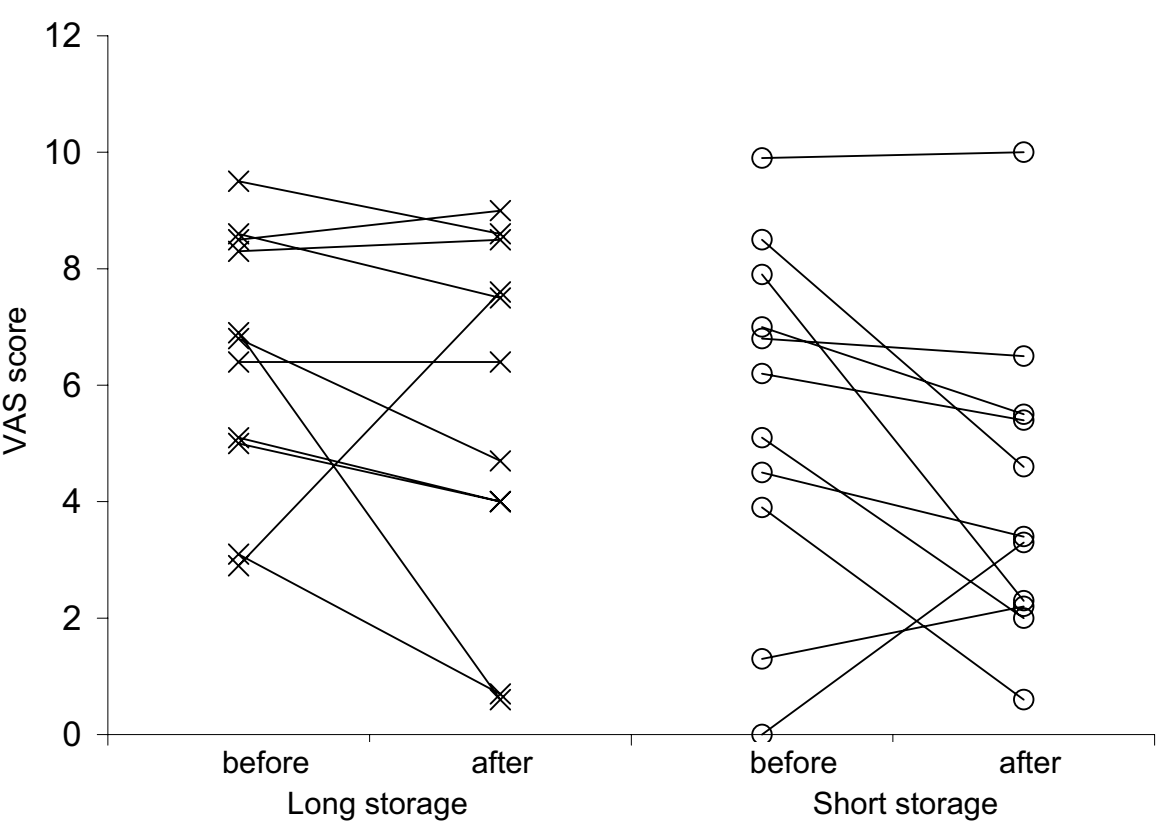

Fig. 1. VAS scores of self-estimated fatigue before and after transfusion in 11 patients receiving $>21$ days old red cells and in 11 patients receiving red cells stored $<7$ days.

Fig. 2. Plasma IL-1b (pg/ml) before and after transfusion in 11 patients receiving $>21$ days old red cells and in 11 patients receiving red cells stored $<7$ days.

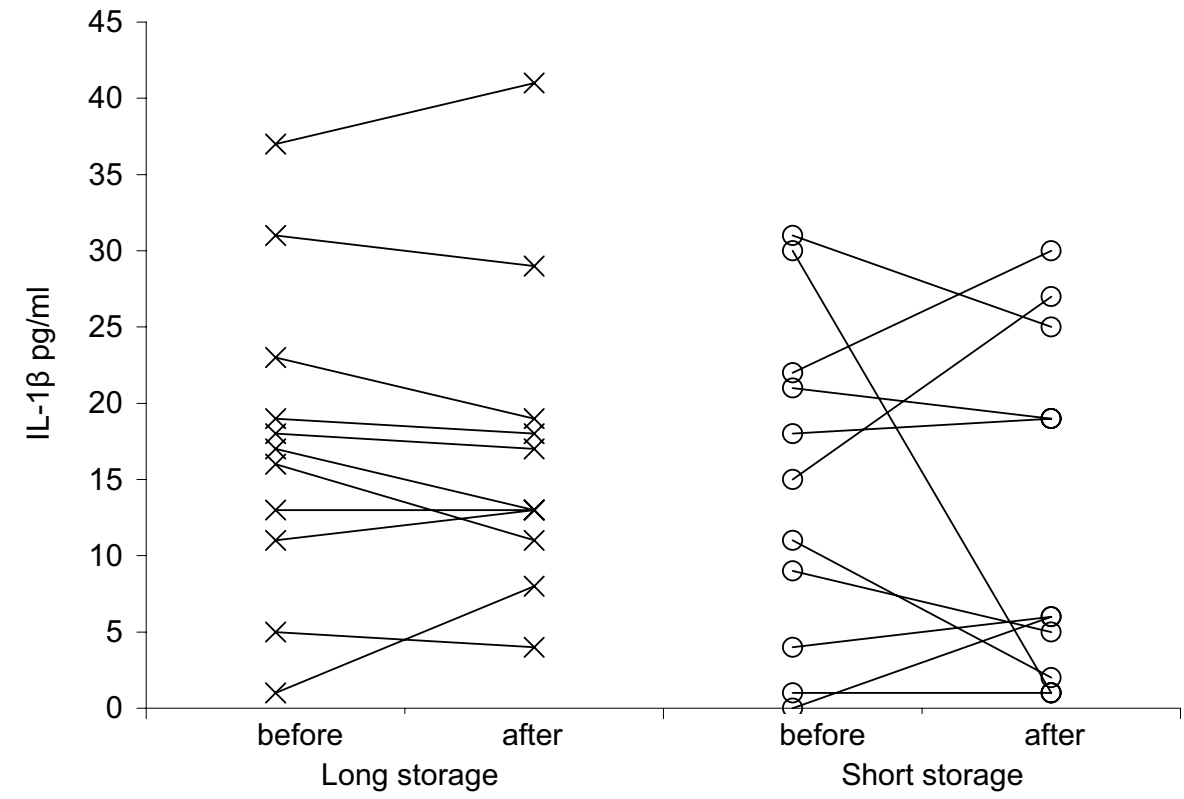

Despite of the quality of the present study, several limitations deserve consideration. First of all, the study population may be to small and to heterogeneous to find a low impact of red cell storage time on post-transfusion cytokine concentrations and fatigue. Secondly the study time frame may be to short and thus not detect long-term effects of transfusion. It should therefore be stressed that the present study set-up does not exclude that cytokines and other inflammatory markers may be elevated when measured in a larger group and especially after longer post-transfusion observation periods. Other cytokines such as vascular endothelial growth factor $[15,16]$ might be sensitive to transfusion with red cells of different storage time. Thirdly fatigue was self-estimated, and objective measures of e.g. walking distance would have added further strength to our study results.

Haemoglobin concentration between 4.5 and $6.0 \mathrm{mmol} / \mathrm{l}$ is only a relative indication for transfusion in normovolaemic patients with no cardiovascular disease in our institution. Selfestimated fatigue was relieved by transfusion of two units of red cells in these mildly anaemic patients, and this was independent of blood storage time. The result should, however, be interpreted in the light of no blinding of the patient receiving red cells. It has previously been shown that blood transfusion may improve well-being and weakness in cancer patients $[2$, 
17], but, with no blinding, it may only be a psychological benefit [18]. Still, it is plausible that the volume effect from blood transfusion may decrease the cardiac and physiologic workload and thereby reduce fatigue. This was supported by our finding that transfusion resulted in improvement of the haemodynamic status, indicated by an increased diastolic pressure. It is reasonable to assume that this 'volume effect' effect may have been identical in the groups receiving blood of short or long storage time, and thereby it could have interfered with a possible difference in fatigue between them. It was interesting to see that not all patients in both groups reported a decrease in fatigue after transfusion, some patients even reported an increase. It should be investigated how the immediate volume-expanding effect of red cell suspension affects fatigue by repeated assessments in the days after transfusion.

In conclusion, this study showed that transfusion of two units of red cells to patients with mild anaemia relieved self-estimated fatigue, but most importantly we found no difference between transfusion of short- and long-stored red cells. Within $2-8 \mathrm{~h}$ after transfusion there was no detectable change in plasma concentrations of the cytokines IL- $1 \beta$, TNF- $\alpha$, IL-6, IL-8, IL-10 and IL-12, indicating no immediate antigenic stimulatory effect from stored transfused red cells. Caution in conclusions should be drawn from the restricted patient number, but the results are useful in the planning of further studies. An indirect effect from stored red cells on cytokine secretion caused by tissue hypoxia or a late stimulation has to be examined by measurements on samples collected more than $8 \mathrm{~h}$ post transfusion. The results are readily applicable in the clinical setting in searching for diagnoses when presented to blood sample abnormalities in a patient right after transfusion.

\section{Acknowledgment}

Bloddonorernes Forskningsfond is thanked for financial support.

\section{References}

1 Ferrario E, Ferrari L, Bidoli P, De Candis D, Del Vecchio M, De Dosso S, Buzzoni R, Bajetta E: Treatment of cancer-related anemia with epoetin alfa: a review. Cancer Treat Rev 2004;30:563-575.

2 Monti M, Castellani L, Berlusconi A, Cunietti E: Use of red blood cell transfusions in terminally ill cancer patients admitted to a palliative care unit. J Pain Symptom Manage 1996;12:18-22.

- 3 Mynster T: Blood transfusion-induced immunomodulation - is storage time important? Dan Med Bull 2003;50:368-384.

${ }_{4}$ Miki C, Hiro J, Ojima E, Inoue Y, Mohri Y, Kusunoki M: Perioperative allogeneic blood transfusion, the related cytokine response and long-term survival after potentially curative resection of colorectal cancer. Clin Oncol (R Coll Radiol) 2006; 18:60-66.

5 Innerhofer P, Tilz G, Fuchs D, Luz G, HobischHagen P, Schobersberger W, Nussbaumer W, Lochs A, Irschick E: Immunologic changes after transfusion of autologous or allogeneic buffy coat-poor versus WBC-reduced blood transfusions in patients undergoing arthroplasty. II. Activation of T cells, macrophages, and cell-mediated lympholysis Transfusion 2000;40:821-827.
6 Izbicki G, Rudensky B, Na’amad M, Hershko C, Huerta M, Hersch M: Transfusion-related leukocytosis in critically ill patients. Crit Care Med 2004; 32:439-442.

7 Kurzrock R: The role of cytokines in cancer-related fatigue. Cancer 2001;92:1684-1688.

8 Chang VT, Hwang SS, Feuerman M: Validation of the Edmonton Symptom Assessment Scale. Cancer 2000;88:2164-2171.

9 Shanwell A, Kristiansson M, Remberger M, Ringden O: Generation of cytokines in red cell concentrates during storage is prevented by prestorage white cell reduction. Transfusion 1997;37:678-684.

10 van Deventer SJ, Buller HR, ten Cate JW, Aarden LA, Hack CE, Sturk A: Experimental endotoxemia in humans: analysis of cytokine release and coagulation, fibrinolytic, and complement pathways. Blood 1990;76:2520-2526.

11 Pruzanski W, Mackensen A, Engelhardt R, Stefanski E, Vadas P: Induction of circulating phospholipase A2 activity by intravenous infusion of endotoxin in patients with neoplasia. J Immunother 1992;12:242-246.

12 O'Brien JM Jr, Abraham E: Human models of endotoxemia and recombinant human activated protein C. Crit Care Med 2004;32:S202-S208.
Zallen G, Moore EE, Ciesla DJ, Brown M, Biff WL, Silliman CC: Stored red blood cells selectively activate human neutrophils to release IL- 8 and secretory PLA2. Shock 2000;13:29-33.

14 Mynster T: Effects of red cell storage and lysis on in vitro cytokine release. Transfus Apheresis Sci 2001; 25:17-23.

15 Werther K, Christensen IJ, Nielsen HJ: The association between preoperative concentration of soluble vascular endothelial growth factor, perioperative blood transfusion, and survival in patients with primary colorectal cancer. Eur J Surg 2001;167: 287-292.

16 Patel HB, Nasir FA, Nash GF, Scully MF, Kakkar AK: Enhanced angiogenesis following allogeneic blood transfusion. Clin Lab Haematol 2004;26: 129-135.

17 Gleeson C, Spencer D: Blood transfusion and its benefits in palliative care. Palliat Med 1995;9: 307-313.

18 Sciortino AD, Carlton DC, Axelrod A, Eng M, Zhukovsky DS, Vinciguerra V: The efficacy of administering blood transfusions at home to terminally ill cancer patients. J Palliat Care 1993;9:14-17. 